\title{
Penambahan Bubuk Daun Stevia Pada Minuman Kopi Arabika Terhadap Tingkat Kesukaan Konsumen
}

\section{Addition of Stevia Leaf Powder to Arabica Coffee Drinks on The Level of Consumer Preference}

\author{
Sepdian Luri Asmono ${ }^{\# 1}$, Alkuin Bangkit Kristiawan*2, Hatmiyarni Tri Handayani*3, Rizky \\ Nirmala Kusumaningtyas*4 \\ ${ }^{1}$ sepdian@polije.ac.id
}

Program Studi Pengelolaan Perkebunan Kopi, Jurusan Produksi Pertanian,

Politeknik Negeri Jember

2alkuinb@gmail.com

${ }^{3}$ hatmiyarni@polije.ac.id

${ }^{4}$ rizky.nk@polije.ac.id

\begin{abstract}
Coffee is one of the beverage ingredients that have been recognized by the Indonesian people. Coffee lovers have various tastes, some of them like the taste of pure coffee without any additions, but some also choose to add sugar as a sweetener to their coffee. Stevia is an alternative to natural sweeteners. However, in Indonesia, the stevia plant has not shown a significant role as a source of sweetener commodities. This study aims to determine the effect of adding stevia leaf powder to arabica coffee drinks on consumer preference. This research used a non-factorial randomized block design with 5\% BNJ Advanced Test which consisted of 5 treatments, namely K1 $(0 \mathrm{gr}), \mathrm{K} 2(0.5$ gr), K3 (1 gr), K4 (1.5 gr) and K5 (2 gr). The results showed that treatment of K1 (0 gr) was the most preferred for aroma and aftertaste parameters, treatment of $\mathrm{K3}(1 \mathrm{gr})$ was most preferred for taste and treatment of $\mathrm{K} 2(0.5 \mathrm{gr})$ was most preferred for viscosity parameters.
\end{abstract}

Keywords : Stevia leaf powder, Arabica coffee

\section{A. Latar Belakang}

\section{Pendahuluan}

Kopi merupakan salah satu komoditi perkebunan dengan nilai ekonomis yang cukup tinggi di antara tanaman perkebunan lainnya dan memiliki peran penting sebagai sumber devisa negara serta menjadi sumber penghasilan bagi para petani kopi di Indonesia. Jenis kopi yang dikenal memiliki nilai ekonomis dan diperdagangkan secara luas adalah kopi arabika dan robusta. Kopi arabika memiliki kualitas cita rasa yang tinggi dan kadar kafein yang lebih rendah dibandingkan dengan kopi jenis robusta[1].

Kopi menjadi salah satu bahan minuman yang telah dikenal oleh masyarakat Indonesia. Berdasarkan
Pusat Data dan Sistem Informasi Pertanian (2017) konsumsi kopi nasional pada tahun 2016 mencapai sekitar 250 ribu ton dan tumbuh 10,54\% menjadi 276 ribu ton. Konsumsi kopi Indonesia sepanjang periode 2016-2021 diprediksi tumbuh ratarata 8,22\%/tahun. Pada 2021 pasokan kopi diperkirakan akan mencapai 795 ribu ton dengan konsumsi 370 ribu ton sehingga terjadi surplus 425 ribu ton.

Saat ini perkembangan minuman kopi tumbuh dengan pesat dan semakin beragam. Banyaknya variasi tambahan pada minuman kopi membuat penikmat kopi memiliki selera yang bermacammacam. Beberapa diantaranya menyukai rasa kopi murni tanpa tambahan apapun, ada yang memilih 
untuk menambahkan gula sebagai pemanis dan ada juga yang menggunakan tanaman herbal untuk ditambahkan pada kopinya. Pemakaian gula yang berlebihan dapat menimbulkan beberapa efek samping, seperti kerusakan pada gigi dan memicu penyakit diabetes. Salah satu cara untuk mengatasi hal tersebut yaitu dengan menggunakan stevia sebagai alternatif pemanis alami.

Dari hasil uji organoleptik yang dilakukan oleh Siauwtama (2016), penggunaan bubuk daun stevia menunjukkan pengaruh yang berbeda nyata pada parameter warna, aroma dan rasa. Pada taraf faktor $0 \%, 0,05 \%, 0,13 \%, 0,21 \%, 0,29 \%$ dan $0,37 \%$ didapatkan perlakuan terbaik dengan penambahan bubuk daun stevia $0,13 \%$ pada minuman teh hijau. Hasil yang didapat pada pengujian perlakuan terbaik adalah parameter warna dengan nilai 5,08 (agak suka); parameter aroma dengan nilai 5,03 (agak suka) dan parameter rasa dengan nilai 4,88 (netral-agak suka). Sedangkan dari hasil uji organoleptik yang dilakukan oleh Santoso [2] dengan taraf faktor yang sama, penggunaan bubuk daun stevia menunjukkan pengaruh yang berbeda nyata pada parameter warna, aroma dan rasa. Didapatkan perlakuan terbaik dengan penambahan bubuk daun stevia $0,29 \%$ pada minuman teh hitam. Hasil yang didapat pada pengujian perlakuan terbaik adalah parameter warna dengan nilai 5,71; parameter aroma dengan nilai 5,29 dan parameter rasa dengan nilai 5,45 .

Di Indonesia, tanaman stevia masih belum menunjukkan peranannya secara nyata sebagai salah satu komoditi sumber pemanis. Banyak negara yang telah menggunakan pemanis stevia hingga berhasil tampil menjadi salah satu komoditi perdagangan baik lokal maupun ekspor. Apabila dipandang dari potensinya, tanaman stevia dapat dipastikan memiliki prospek yang baik untuk dikembangkan di Indonesia. Berdasarkan uraian di atas perlu dilakukan penelitian terkait penambahan bubuk daun stevia sebagai pemanis dalam minuman kopi untuk mengetahui tingkat kesukaan konsumen.

\section{Metodologi}

\section{A. Waktu dan Tempat}

Pelaksanaan penelitian dengan judul "Penambahan Bubuk Daun Stevia Pada Minuman Kopi Arabika Terhadap Tingkat Kesukaan Konsumen" dilaksanakan pada bulan Oktober sampai bulan Desember 2020 di Laboratorium Pengolahan Hasil Tanaman Pertanian Politeknik Negeri Jember.

\section{B. Alat dan Bahan}

Alat yang digunakan pada penelitian ini yaitu mangkok cupping, sendok cupping, termometer, gelas ukur, kompor, blender, ceret, timbangan, gelas, penyaring, nampan. Bahan yang digunakan dalam penelitian ini yaitu bubuk kopi arabika argopuro (roasting medium), daun stevia kering, air, label.

\section{Metode Penelitian}

Penelitian ini disusun menggunakan Rancangan Acak Kelompok (RAK) non-faktorial yang terdiri atas 5 perlakuan pada kopi yang ditambahkan dengan bubuk daun stevia (0 gram, 0,5 gram, 1 gram, 1,5 gram, 2 gram).

\begin{tabular}{ccc}
\multicolumn{2}{c}{ TABEL 1. PERLAKUAN } \\
\hline No & Perlakuan & Bubuk daun stevia \\
\hline 1. & K1 & 0 gram \\
2. & K2 & 0,5 gram \\
3. & K3 & 1 gram \\
4. & K4 & 1,5 gram \\
5. & K5 & 2 gram \\
\hline
\end{tabular}

Adapun model statistik Rancangan Acak Kelompok (RAK) yang digunakan :

$$
Y_{i j}=\mu+\tau_{i}+\alpha_{j}+\varepsilon_{i j}
$$

Keterangan :

$\mathrm{Y}_{\mathrm{ij}}$ : Nilai pengamatan dari perlakuan ke-i pada kelompok ke-j

$\mu \quad$ : Nilai tengah umum

$\tau_{\mathrm{i}}$ : Pengaruh kelompok ke-i

$\alpha_{\mathrm{j}}$ : Pengaruh perlakuan ke-j

$\varepsilon_{\mathrm{ij}}$ : Acak galat percobaan dari kelompok ke-i dan perlakuan ke-j

Data yang diperoleh dianalisis dengan menggunakan analisa ragam (ANOVA). Apabila terdapat perbedaan yang nyata dilanjutkan dengan uji lanjut BNJ (Beda Nyata Jujur) dengan taraf 5\%.

Panelis yang dilibatkan dalam penelitian ini merupakan panelis tidak terlatih sebanyak 100 panelis. Panelis yang digunakan dalam penelitian ini memiliki kategori sebagai berikut : laki-laki 49 orang, perempuan 51 orang, berumur 20-30 tahun 91 orang, berumur lebih dari 30 tahun 9 orang.

\section{Prosedur Pelaksanaan}

- Pembuatan Bubuk Daun Stevia

a) Menyiapkan daun stevia kering.

b) Menghaluskan daun stevia kering menggunakan blender.

c) Melakukan penyaringan pada daun stevia yang telah dihaluskan hingga mendapatkan bubuk daun stevia.

- Uji Organoleptik

a) Menyiapkan alat dan bahan yang akan digunakan.

b) Meletakkan bubuk kopi pada cupping bowl dengan takaran 8,25 gram untuk setiap $150 \mathrm{ml}$ air.

c) Menambahkan bubuk daun stevia pada cupping bowl sesuai perlakuan (0 gram, 0,5 gram, 1 gram, 1,5 gram, 2 gram).

d) Memanaskan air hingga $93^{\circ} \mathrm{C}$. 
Sepdian Luri Asmono, Alkuin Bangkit Kristiawan, Hatmiyarni Tri Handayani, Rizky Nirmala Kusumaningtyas. Penambahan Bubuk Daun Stevia Pada Minuman Kopi Arabika Terhadap Tingkat Kesukaan Konsumen

e) Menyeduh kopi dengan air yang sudah dipanaskan.

f) Panelis melakukan penilaian terhadap kopi yang sudah diseduh.

\section{E. Parameter Pengamatan}

Parameter pengamatan selama kegiatan penelitian meliputi aroma, rasa, kekentalan dan aftertaste.

Contoh Pemberian Penilaian :

Tidak suka

Penempatan pemberian garis menunjukkan tingkat kesukaan panelis dalam menilai. Apabila semakin ke kanan maka semakin suka sedangkan semakin ke kiri maka semakin tidak suka.

\section{Hasil Dan Pembahasan}

\section{A. Hasil}

Berdasarkan hasil penelitian, data yang diperoleh dari parameter aroma, rasa, kekentalan dan aftertaste kemudian dianalisis menggunakan analisa ragam (ANOVA). Berikut merupakan rekap hasil dari data yang telah dianalisis.

TABEl 2. ReKAP HASIl Uji ANOVA TERHADAP KOPI DENGAN PENAMBAHAN BUBUK DAUN STEVIA

\begin{tabular}{|c|c|c|c|c|}
\hline Parameter & F Hitung & F 5\% & F 1\% & Notasi \\
\hline Aroma & 9,023 & 2,418 & 3,416 & $* *$ \\
\hline Rasa & 5,424 & 2,418 & 3,416 & $* *$ \\
\hline Kekentalan & 1,134 & 2,418 & 3,416 & $\mathrm{~ns}$ \\
\hline Aftertaste & 3,222 & 2,418 & 3,416 & $*$ \\
\hline
\end{tabular}

Ket $:$ ns $=$ berbeda tidak nyata, $*=$ berbeda nyata, $* *=$ berbeda sangat nyata

\section{B. Pembahasan}

- Aroma

Aroma menjadi salah satu parameter penting karena dapat langsung mempengaruhi persepsi rasa enak dari suatu makanan atau minuman. Pada minuman kopi, aromanya yang khas merupakan keunggulan dari minuman tersebut. Aroma kopi yang beraneka ragam mampu menjadikan kopi sebagai salah satu minuman yang digemari banyak orang. Dalam industri pangan, pengujian aroma dianggap penting karena dengan cepat dapat memberikan penilaian terhadap hasil produksinya, apakah produksinya disukai atau tidak oleh konsumen [3].

Hasil yang didapat dari uji organoleptik terhadap tingkat kesukaan aroma minuman kopi arabika dengan penambahan bubuk daun stevia menunjukkan berbeda sangat nyata. Berikut merupakan diagram batang uji organoleptik parameter aroma.

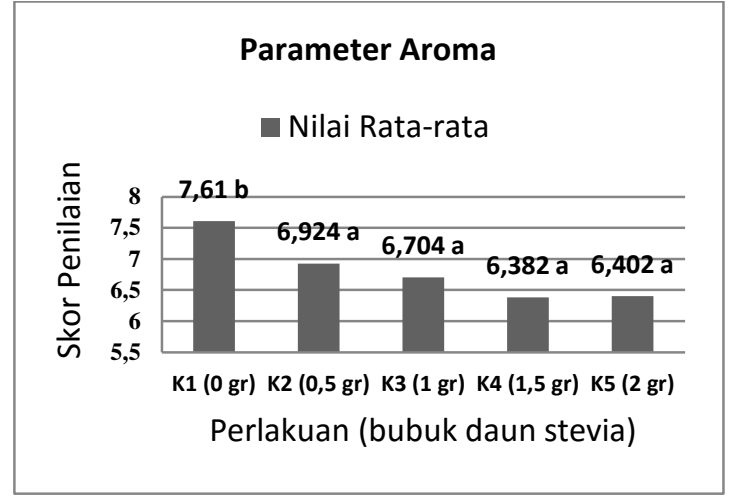

GAMBAR 1. NILAI PARAMETER AROMA

Pada diagram di atas dapat diketahui bahwa minuman kopi arabika tanpa penambahan bubuk daun stevia merupakan minuman kopi arabika yang memiliki tingkat kesukaan aroma paling tinggi dengan nilai rata-rata 7,61. Panelis lebih menyukai aroma minuman kopi arabika tanpa penambahan bubuk daun stevia karena bubuk daun stevia memiliki aroma kurang harum, aroma yang dihasilkan cenderung seperti minuman herbal/jamu. Menurut Lee [4], aroma tidak menyenangkan pada daun berupa aroma langu berasal dari kelompok senyawa aldehid alifatik yaitu senyawa volatile 3methylbutanal.

Hasil ANOVA pada parameter aroma di tabel 2 menunjukkan bahwa penambahan bubuk daun stevia pada minuman kopi arabika berpengaruh sangat nyata terhadap tingkat kesukaan panelis. Hal ini dapat dilihat dari nilai $\mathrm{F}$ hitung yang lebih besar dari nilai $\mathrm{F}$ $1 \%$, ditunjukkan dengan notasi “**” atau berbeda sangat nyata sehingga dilakukan uji lanjut BNJ dengan taraf $5 \%$.

Berdasarkan gambar 1, perlakuan K1 ( 0 gr) yaitu tanpa penambahan bubuk daun stevia memiliki notasi yang berbeda dengan perlakuan K2 (0,5 gr), K3 (1 gr), K4 (1,5 gr) dan K5 (2 gr). Perlakuan dengan notasi yang berbeda menunjukkan adanya pengaruh yang berbeda nyata/sangat nyata sedangkan untuk yang notasinya sama menunjukkan berbeda tidak nyata. Gambar 1 juga menunjukkan bahwa perlakuan tanpa bubuk daun stevia lebih disukai dari perlakuan yang menggunakan bubuk daun stevia.

- Rasa

Rasa didefinisikan sebagai rangsangan yang ditimbulkan oleh suatu bahan yang dimakan atau dirasakan oleh indera pengecap atau pembau, serta rangsangan lainnya seperti perabaan dan penerimaan derajat panas oleh mulut. Parameter rasa berperan dalam menentukan tingkatan penerimaan dari suatu bahan pangan oleh konsumennya[5]

Hasil uji organoleptik terhadap tingkat kesukaan rasa minuman kopi arabika dengan penambahan bubuk daun stevia menunjukkan berbeda sangat 
nyata. Berikut ini merupakan diagram batang uji organoleptik parameter rasa.

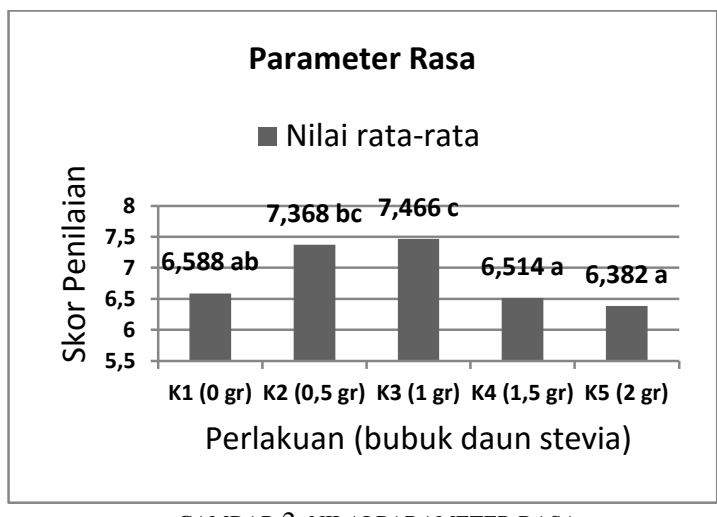

GAMBAR 2. NILAI PARAMETER RASA

Pada diagram di atas dapat diketahui bahwa minuman kopi arabika dengan penambahan bubuk daun stevia $1 \mathrm{gr}$, merupakan kopi yang memiliki tingkat kesukaan rasa paling tinggi dengan nilai ratarata 7,466. Menurut Savita [6] , bubuk daun stevia yang masih hijau memberikan rasa manis 30 kali dibandingkan sukrosa. Rasa manis pada daun stevia berasal dari senyawa steviosida. Tingkat kemanisan steviosida yang tinggi, menyebabkan penggunaan stevia dalam jumlah banyak akan memberikan rasa yang terlalu manis.

Hasil ANOVA pada parameter rasa di tabel 2 menjelaskan bahwa penambahan bubuk daun stevia pada minuman kopi arabika berpengaruh sangat nyata terhadap tingkat kesukaan panelis. Hal ini dapat dilihat dari nilai $\mathrm{F}$ hitung yang lebih besar dari nilai $\mathrm{F}$ $1 \%$ yang ditunjukkan dengan notasi “**" atau berbeda sangat nyata sehingga dilakukan uji lanjut BNJ dengan taraf 5\%.

Berdasarkan gambar 2, perlakuan K3 (1 gr) berpengaruh tidak nyata terhadap perlakuan $\mathrm{K} 2(0,5$ gr) tetapi berpengaruh nyata/sangat nyata terhadap perlakuan K1 (0 gr), K4 (1,5 gr) dan K5 (2 gr). Perlakuan K2 $(0,5 \mathrm{gr})$ berpengaruh tidak nyata dengan perlakuan K3 (1 gr) dan K1 (0 gr) tetapi berpengaruh nyata/sangat nyata terhadap perlakuan K4 (1,5 gr) dan K5 (2 gr). Perlakuan dengan notasi yang berbeda menunjukkan adanya pengaruh yang berbeda nyata/sangat nyata sedangkan untuk yang notasinya sama menunjukkan berbeda tidak nyata.

\section{- Kekentalan}

Kekentalan juga merupakan faktor kuat yang mendukung tingkat kesukaan seseorang terhadap kopi selain aroma, cita rasa dan aftertaste. Perbandingan air dan ekstrak memiliki pengaruh terhadap warna, rasa dan aroma. Semakin besar perbandingan air yang ditambahkan maka warna akan semakin terang hingga pucat, aromanya kurang khas, rasa akan semakin hambar serta kekentalannya pun rendah dan sebaliknya.
Hasil uji organoleptik terhadap tingkat kesukaan kekentalan minuman kopi arabika dengan penambahan bubuk daun stevia menunjukkan berbeda tidak nyata. Berikut ini merupakan diagram batang uji organoleptik parameter kekentalan.

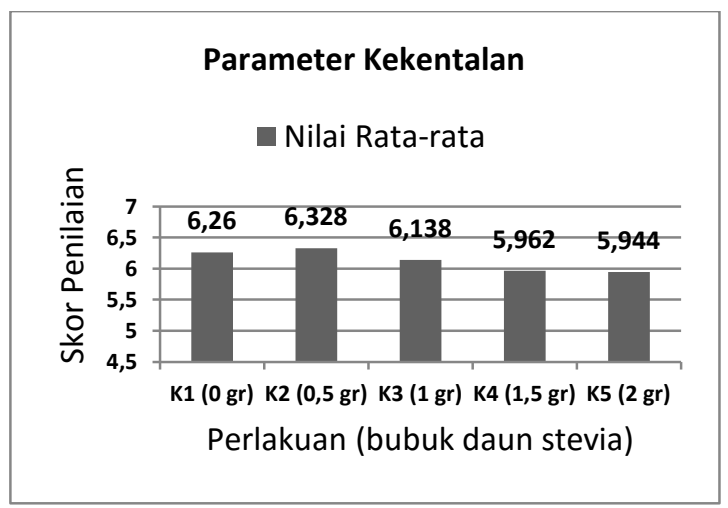

GAMBAR 3. NILAI PARAMETER KEKENTALAN

Pada diagram di atas dapat diketahui bahwa minuman kopi arabika dengan penambahan bubuk daun stevia 0,5 gram, merupakan kopi yang memiliki tingkat kesukaan kekentalan paling tinggi dengan nilai rata-rata 6,328. Perbandingan bubuk kopi dan air (8,25 gram bubuk kopi : $150 \mathrm{ml}$ air atau 1:18) yang sama tiap perlakuannya, menjadikan kekentalan pada minuman kopi tidak terlalu berbeda. Namun, adanya penambahan bubuk daun stevia juga dapat mempengaruhi kekentalan dari minuman kopi itu sendiri.

Hasil ANOVA pada parameter kekentalan di tabel 2 menjelaskan bahwa penambahan bubuk daun stevia pada minuman kopi arabika berpengaruh tidak nyata terhadap tingkat kesukaan panelis. Hal ini dapat dilihat dari nilai $\mathrm{F}$ hitung yang lebih kecil dari nilai $\mathrm{F}$ $5 \%$ yang ditunjukkan dengan notasi "ns" (nonsignifikan) atau tidak berbeda nyata sehingga tidak perlu dilakukan uji lanjut.

\section{- Aftertaste}

Aftertaste kopi yang baik dapat memberikan kesan yang baik pula terhadap kopi yang diminumnya. Pada penelitian ini, aftertaste kopi yang dihasilkan dari penambahan bubuk daun stevia yaitu aftertaste yang manis-pahit dan langu tergantung dari takaran bubuk daun stevia yang diberikan pada kopi. Hasil yang didapat dari uji organoleptik terhadap tingkat kesukaan aftertaste minuman kopi arabika dengan penambahan bubuk daun stevia menunjukkan berbeda nyata. Berikut ini merupakan diagram batang uji organoleptik parameter aftertaste. 
Sepdian Luri Asmono, Alkuin Bangkit Kristiawan, Hatmiyarni Tri Handayani, Rizky Nirmala Kusumaningtyas. Penambahan Bubuk Daun Stevia Pada Minuman Kopi Arabika Terhadap Tingkat Kesukaan Konsumen

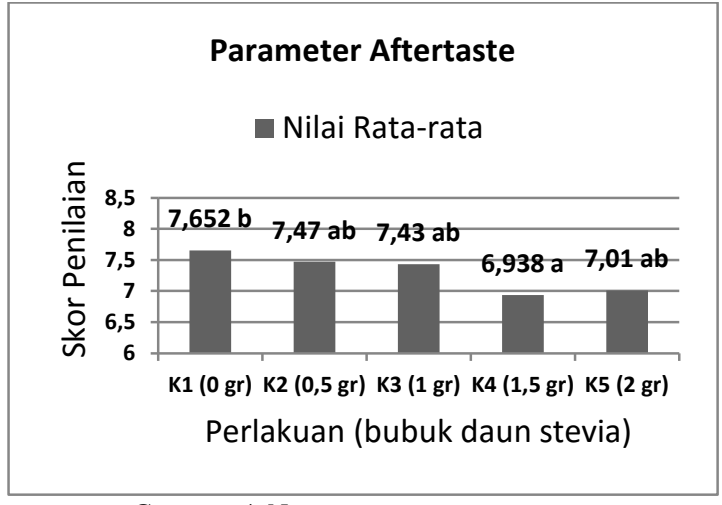

GAMBAR 4. NILAI PARAMETER AFTERTASTE

Pada diagram di atas dapat diketahui bahwa minuman kopi arabika tanpa penambahan bubuk daun stevia merupakan kopi yang memiliki tingkat kesukaan aftertaste paling tinggi dengan nilai ratarata 7,652. Hasil penelitian yang dilakukan Tezar (2008) menyebutkan bahwa pada kombinasi $8 \%$ sukrosa dengan penambahan $1 \%$ ekstrak stevia pada sari buah belimbing manis memiliki tingkat kepahitan sebesar 0,9 dengan batas atau titik tidak pahit sebesar 0,3 . Hal tersebut menjelaskan bahwa pada penambahan ekstrak stevia $1 \%$ sudah memiliki sedikit rasa pahit. Menurut Hastuti dan Rustanti (2014) stevia dalam bentuk daun kering dapat mengurangi bitter-aftertaste. Rebaudiosida-A merupakan komponen yang menimbulkan bitteraftertaste. Dalam bentuk ekstrak, bitter-aftertaste lebih terasa.

Hasil ANOVA pada parameter aftertaste di tabel 2 menunjukkan bahwa penambahan bubuk daun stevia pada minuman kopi arabika berpengaruh nyata terhadap tingkat kesukaan panelis. Hal ini dapat dilihat dari nilai $\mathrm{F}$ hitung yang lebih besar dari nilai $\mathrm{F}$ $5 \%$ namun masih lebih kecil dari nilai $\mathrm{F} 1 \%$ yang ditunjukkan dengan notasi "** atau berbeda nyata sehingga dilakukan uji lanjut BNJ dengan taraf 5\%.

Berdasarkan gambar 4, perlakuan K1 (0 gr) yaitu tanpa penambahan bubuk daun stevia memiliki notasi yang berbeda dengan perlakuan $\mathrm{K} 2$ (0,5 gr), K3 (1 gr), K4 (1,5 gr) dan K5 (2 gr) yang memiliki notasi yang sama. Perlakuan dengan notasi yang berbeda menunjukkan adanya pengaruh yang berbeda nyata/sangat nyata. Pemberian bubuk daun stevia dalam jumlah yang banyak akan berpengaruh terhadap aftertaste minuman kopi arabika. Selain menimbulkan rasa pahit, bubuk daun stevia juga akan menimbulkan aftertaste langu / tidak enak sehingga mempengaruhi tingkat kesukaan konsumen.

\section{KESIMPULAN DAN SARAN}

\section{A. Kesimpulan}

Hasil penelitian ini menunjukkan bahwa penambahan bubuk daun stevia pada minuman kopi arabika berpengaruh sangat nyata terhadap tingkat kesukaan konsumen yang meliputi parameter aroma dan rasa, berpengaruh nyata pada parameter aftertaste dan tidak berpengaruh nyata pada parameter kekentalan. Komposisi penambahan bubuk daun stevia pada minuman kopi arabika yang paling disukai konsumen untuk parameter aroma yaitu perlakuan K1 dengan komposisi 8,25 gram bubuk kopi +0 gram bubuk daun stevia $+150 \mathrm{ml}$ air, untuk parameter rasa yaitu perlakuan K3 dengan komposisi 8,25 gram bubuk kopi +1 gram bubuk daun stevia + $150 \mathrm{ml}$ air, untuk parameter kekentalan yaitu perlakuan K2 dengan komposisi 8,25 gram bubuk kopi $+0,5$ gram bubuk daun stevia $+150 \mathrm{ml}$ air dan untuk parameter aftertaste yaitu perlakuan $\mathrm{K} 1$ dengan komposisi 8,25 gram bubuk kopi +0 gram bubuk daun stevia $+150 \mathrm{ml}$ air.

\section{B. Saran}

Penelitian ini memerlukan penelitian lebih lanjut untuk mendapatkan sifat-sifat organoleptik minuman kopi dengan penambahan bubuk daun stevia yang lebih baik. Penggunaan jenis kopi dengan aroma yang lebih kuat dan penambahan bahan lainnya perlu dipertimbangkan, mengingat aroma yang dihasilkan berbau herbal dan masih jarang yang menyukainya.

\section{DAfTAR PUSTAKa}

[1] Gustianova, H. 2012. Perbandingan Ekstrak Salak Dengan Air Terhadap Karakteristik Minuman Ekstrak Buah Salak Bongkok (Salacca edulis Reinw)...pp.1-21

[2] Hastuti, A.M. and N. Rustanti. 2014. Pengaruh Penambahan Kayu Manis Terhadap Aktivitas Antioksidan Dan Kadar Gula Total Minuman Fungsional Secang Dan Daun Stevia Sebagai Alternatif Minuman Bagi Penderita Diabetes Melitus Tipe 2. Journal of Nutrition College, 3(3). pp.362369.

[3] Lee, J., D.H. Chambers, E. Chambers IV, K. Adhikari, and Y. Yoon. 2013. Volatile Aroma Compounds In Various Brewed Green Teas. Molecules, 18(8). pp.10024-10041.

[4] Prabandari, W. 2011. Pengaruh Berbagai Jenis Bahan Penstabil Terhadap Karakteristik Fisikokimia dan Organoleptik Yoghurt Jagung.

[5] Pusat Data dan Sistem Informasi Pertanian. 2017. Outlook Kopi 2017. Kementerian Pertanian.

[6] R., T., S. Aminah, and A. Bain. 2008. Optimasi Pemanfaatan Stevia Sebagai Pemanis Alami Pada Sari Buah Blimbing Manis. . p.10.

[7] Rahardjo, P. 2012. Kopi Panduan Budidaya \& Pengolahan Kopi Arabika dan Robusta. Jakarta: Penebar Swadaya.

[8] S.M. Savita, K. Sheela, Sharan Sunanda, A.G.S. \&Parama R. 2004. Stevia rebaudiana - A Functional Component for Food Industry. Journal of Human Ecology, 15(4). pp.261-264. 
Jurnal IImiah INOVASI, Vol. 21 No. 1 Januari-April 2021, ISSN 1411-5549

[9] Santoso, G.N. 2016. Pengaruh Penambahan Bubuk Daun Stevia (Stevia rebaudiana Bertoni $M$ ) Terhadap Sifat Fisikokimia dan Sifat Organoleptik Pada Minuman Teh Hitam Stevia. Widya Mandala Catholic University Surabaya.

[10] Siauwtama, E. 2016. Pengaruh Penambahan Bubuk Daun Stevia (Stevia rebaudiana Bertoni M) Terhadap Sifat Fisikokimia dan Organoleptik Pada Minuman Teh Hijau. Widya Mandala Catholic University Surabaya.

[11] Soekarto, S.T. 1985. Penilaian Organoleptik: Untuk Industri Pangan dan Hasil Pertanian / Soewarno T. Soekarto. Bharata Karya Aksara. 